\title{
C-REACTIVE PROTEIN IN DIABETIC PATIENTS BEFORE GASTRIC BYPASS AS A POSSIBLE MARKER FOR POSTOPERATIVE COMPLCATION
}

\author{
Proteína c reativa em diabéticos antes do bypass gástrico como possível marcador de complicação pós-operatória \\ Daniel C. LINS ${ }^{1,2}$, Josemberg M. CAMPOS2; Patrícia S. de PAULA², Manoel GALVÃO-NETO², \\ Eduardo PACHU' ${ }^{2}$, Ney CAVALCANTII ${ }^{1}$ Álvaro A. B. FERRAZ ${ }^{2}$
}

From the ${ }^{1}$ Serviço de Endocrinologia, Hospital Oswaldo Cruz, Faculdade de Ciências Médicas de Pernambuco, and ${ }^{2}$ Serviço de Cirurgia Geral/Pós-graduação em Cirurgia, Universidade Federal de Pernambuco ('Service of Endocrinology, Oswaldo Cruz Hospital, Faculty of Medical Sciences of Pernambuco, and 2 Service of General Surgery/Post-graduation in Surgery, Federal University of Pernambuco), Recife, PE, Brazil

HEADINGS - Bariatric Surgery. Diabetes Mellitus, Type 2. Obesity. Roux-en-Y anastomosis. Gastric bypass. C-reactive protein. Postoperative complications.
ABSTRACT - Background: Obesity and type 2 diabetes mellitus are associated to inflammatory state, which can be set off by the adipose tissue, once it is a metabolically active organ that can cause a chronic mild inflammatory state. Aim: To evaluate the correlation between preoperative C-reactive protein and postoperative complications risk in obese patients (grades II and III) after Roux-en-Y gastric bypass, with and without type 2 diabetes mellitus. Methods: Between 2008 and 2013 were analysed 209 patients (107 with diabetes), presenting body mass index $>40 \mathrm{~kg} / \mathrm{m}^{2}$ or $>35 \mathrm{~kg} / \mathrm{m}^{2}$ with comorbidities. During the postoperative period, two groups were evaluated: with and without complications. Preoperative ultra-sensitive C-reactive protein was measured by immunonephelometry method. Results: Complications occurred in seven patients (pulmonary thromboembolism, fistula, two cases of suture leak, pancreatitis, evisceration and upper digestive hemorrhage). No statistical significance was found regarding lipid profile and C-reactive protein between patients with and without type 2 diabetes mellitus. When compared to each other, both groups (with and without complications) presented with statistical significance regarding C-reactive protein level $(7,2 \mathrm{mg} / \mathrm{dl}$ vs $3,7 \mathrm{mg} / \mathrm{dl}, \mathrm{p}=0,016)$ and had similar weight loss percentage after 3, 6 and 12 months follow-up. Conclusions: Preoperative C-reactive protein serum level was higher in the group which presented complications after Roux-en-Y gastric bypass when compared to the group without postoperative complications.

\section{Correspondence:}

Josemberg M. Campos

E-mail:josembergcampos@gmail.com

Financial source: none

Conflicts of interest: none

Received for publication: 26/02/2015

Accepted for publication: 02/06/2015

DESCRITORES: Cirurgia bariátrica. Diabetes mellitus tipo 2. Obesidade. Derivação gástrica em Y-de-Roux. Derivação gástrica. Proteina C reativa. Complicações pósoperatórias.
RESUMO - Racional: Obesidade e diabete melito tipo 2 são associadas a estado inflamatório desencadeado pelo tecido adiposo, uma vez que é órgão metabolicamente ativo e que pode gerar estado de inflamação crônica leve. Objetivo: Avaliar a correlação entre os níveis de proteína $C$ reativa pré-operatória e o risco de complicações pós-operatórias em obesos graus II e III após bypass gástrico em Y-de-Roux, em um grupo com e outro sem diabete melito tipo 2. Métodos: Entre 2008 e 2013 foram analisados 209 pacientes (107 diabéticos) com índice de massa corpórea acima de $40 \mathrm{~kg} / \mathrm{m}^{2}$ ou maior que $35 \mathrm{~kg} / \mathrm{m}^{2}$ com comorbidades. No pós-operatório foi avaliado um grupo com e outro sem complicações. A proteína $\mathrm{C}$ reativa ultrassensível pré-operatória foi mensurada pela técnica de imunonefelometria. Resultados: Complicações ocorreram em sete pacientes (tromboembolismo pulmonar, fístula, dois casos de vazamento de sutura, pancreatite, evisceração e hemorragia digestiva alta). Não houve diferença estatística significativa em relação ao perfil lipídico e níveis séricos de proteína $C$ reativa entre os grupos com e sem diabete. Quando comparados, os dois grupos (com e sem complicações) apresentaram significância estatística entre os níveis de proteína $C$ reativa $(7,2$ $\mathrm{mg} / \mathrm{dl}$ vs $3,7 \mathrm{mg} / \mathrm{dl}, \mathrm{p}=0,016$ ), sendo semelhantes em relação à percentagem de perda de peso após seguimento de 3, 6 e 12 meses. Conclusões: $O$ nível sérico de proteína $C$ reativa préoperatória foi mais elevado no grupo com complicações após bypass gástrico em Y-de-Roux do que no grupo sem complicações.

$\mathrm{T}$ he prevalence of overweight and obesity is growing throughout the world, increasing the frequency of comorbidities such as type 2 diabetes mellitus (DM2). Obesity and DM2 are conditions frequently associated with a chronic inflammatory state ${ }^{28}$. This association may be explained by the increase in circulating levels of various inflammatory markers, such as pro-inflammatory cytokines and proteins of the acute phase, such as interleukin 6 (IL-6), tumor necrosis factor $\alpha$ and $\mathrm{C}$-reactive protein (CPR). The latter plays an important role in the response to systemic inflammation, increasing the plasma concentration during inflammatory processes ${ }^{6,24}$.

Bariatric surgery is a safe process with a mortality rate of less than $0.3 \%$. Early complications may occur in up to $13 \%$ of patients ${ }^{23}$. There are, however, no markers to safely determine the risk of postoperative complications. There are no studies in the literature that assess the relation between levels of pre-operative CPR and the risk of complications after Roux-en-Y gastric bypass (RYGB). 
Some studies that involve different surgical specialties report higher serum levels of CPR with infectious postoperative complications ${ }^{8,17}$. The increase in pre-operative CPR was considered a risk factor for infection and an increase in hospital mortality for heart surgery, as well as increasing the risk of suture leakage and other infectious complications after elective colorectal surgery ${ }^{8,29}$.

There is evidence of an association between the accumulation of adipose tissue and an increase in levels of CPR and adipose tissue is known to be a metabolically active organ that may cause a low-intensity chronic inflammatory state 11,20,22,25. $^{2}$.

The effect of weight loss after bariatric surgery on levels of inflammatory cytokines and markers of inflammation has been demonstrated ${ }^{13,30}$. After the surgical procedure, there is a reduction in CPR serum levels (65\%, on average), according to weight loss ${ }^{3}$. However, there is no studies that assess the relation between heightened levels of CPR prior to RYGB and the occurrence of postoperative complications.

The aim of the present study was to assess the correlation between pre-operative levels of CPR and the risk of complications in individuals with grade II and grade III obesity after RYGB in one group with and one without DM2.

\section{METHODS}

Two hundred and nine patients ( 65 men and 144 women) who had undergone RYGB at the General Surgery Service of the Federal University of Pernambuco's Hospital das Clínicas, Recife, PE, Brazil between 2008 and 2013 were analyzed retrospectively. The mean age was 40.2 years and the mean body mass index (BMI) $41.5 \mathrm{~kg} / \mathrm{m}^{2}$. Type 2 diabetes mellitus was present in 107 patients, as diagnosed according to the criteria of the American Diabetes Association. The mean time for diagnosis of DM2 was 4.4 years. Bariatric surgery was recommended when BMI was greater than $40 \mathrm{~kg} / \mathrm{m}^{2}$ or 35 $\mathrm{kg} / \mathrm{m}^{2}$ with comorbidities.

The ultrasensitive CPR was measured preoperatively using the immunonephelometry technique. For evaluation of inflammatory/infectious processes the reference value used was greater than $5 \mathrm{mg} / \mathrm{dl}$. The reference values used for evaluation of cardiovascular risk were as follows: low risk: $<1.00$ $\mathrm{mg} / \mathrm{l}$; moderate risk: $1.00-3.00 \mathrm{mg} / \mathrm{dl}$; high risk: $>3.00 \mathrm{mg} / \mathrm{dl}$.

Serum biochemical tests were carried out by collecting blood samples $(20 \mathrm{ml})$ from a peripheral vein by a single puncture in the morning on the day before the operation, after a period of rest and minimum fasting of $8 \mathrm{~h}$. Laboratory tests included fasting glycemia, total cholesterol and fractions, and triglycerides.

Total cholesterol and fractions were measured in serum using an Analisa diagnostic kit, based principally on the colorimetric enzyme method. The desirable reference level for cholesterol was $<200 \mathrm{mg} / \mathrm{dl}$ and for triglycerides $<150 \mathrm{mg} / \mathrm{dl}$.

All patients underwent laparoscopic RYGB with the creation of a gastric pouch with an approximate volume of $50 \mathrm{ml}$, a biliopancreatic diversion $100 \mathrm{~cm}$ in length and a $150 \mathrm{~cm}$ alimentary diversion. Intraoperative glucose was monitored using capillary glycemia and corrected with regular subcutaneous insulin, when necessary, to keep glycemia between 80 and $140 \mathrm{mg} / \mathrm{dl}$.

The patients were divided into two groups: with and without postoperative complications (up to 30 days). Outpatient follow-up began 15 days after the RYGB, with further consultations after $1,2,6$ and 12 months, followed by at least one consultation per year (Figure 1).

The level of significance adopted for statistical tests was $5 \%$. Data analysis was carried out using inferential statistical techniques and Student's $t$ and the Mann-Whitney tests.

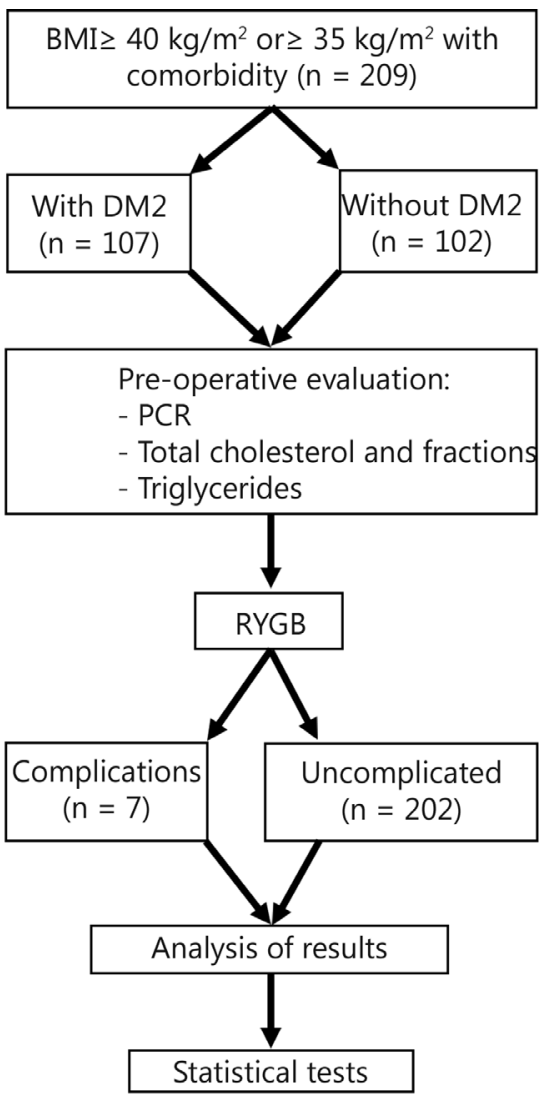

FIGURE 1 - Flow Chart

\section{RESULTS}

The patients (with and without DM2) had a similar preoperative lipid and inflammatory profiles (Table 1 ).

After the RYGB, the data from the groups with and without complications were analyzed. Complications occurred in seven patients: pulmonary thromboembolism, fistula, suture leakage $(n=2)$, pancreatitis, evisceration and upper digestive tract hemorrhage. The group with complications had a significantly higher level of CRP than the one without $(p=0.016)$ (Figure 2$)$.

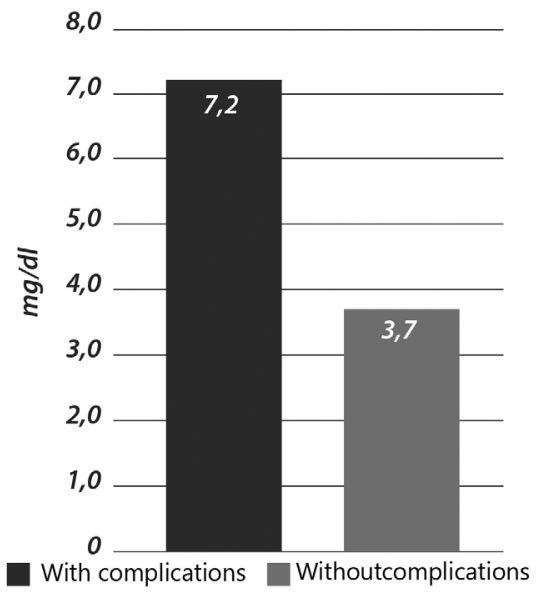

FIGURE 2 - Preoperative CRP vs surgical complications

There was no difference in weight loss after 3, 6 and 12 months between the two groups. The occurrence of surgical complications did not influence weight loss after follow-up. The mean weight loss after one year of follow-up was 33.42 $\mathrm{kg}( \pm 6.97)$ and $33.79 \mathrm{~kg}( \pm 5.80)$ in patients with and without complications, respectively (Tables 2 and 3 ). 
TABLE 1 - Comparison of diabetic and non-diabetic groups

\begin{tabular}{|c|c|c|c|}
\hline \multirow{2}{*}{ Variables } & \multicolumn{2}{|c|}{ Diabetes } & \multirow[b]{2}{*}{$p$} \\
\hline & Yes & No & \\
\hline - Total cholesterol & $\begin{array}{c}208.09 \mathrm{mg} / \mathrm{dl} \\
\quad \pm 42.52)\end{array}$ & $\begin{array}{c}200.88 \mathrm{mg} / \mathrm{dl} \\
( \pm 37.20)\end{array}$ & $\mathrm{p}^{(1)}=0.249$ \\
\hline - Triglycerides & $\begin{array}{c}184.75 \mathrm{mg} / \mathrm{dl} \\
( \pm 94.84)\end{array}$ & $\begin{array}{c}160.60 \mathrm{mg} / \mathrm{dl} \\
( \pm 100.18)\end{array}$ & $\mathrm{p}^{(1)}=0.135$ \\
\hline CPR & $\begin{array}{c}3.86 \mathrm{mg} / \mathrm{dl} \\
( \pm 0.64)\end{array}$ & $\begin{array}{c}3.65 \mathrm{mg} / \mathrm{dl} \\
( \pm 0.42)\end{array}$ & $\mathrm{p}^{(1)}=0.640$ \\
\hline
\end{tabular}

(1)=Student's $t$ test
TABLE 2 - Comparison of weight loss in groups with and without complications

\begin{tabular}{|c|c|c|c|}
\hline \multirow{2}{*}{ Variables } & \multicolumn{2}{|c|}{ Complications } & \multirow{2}{*}{$p$} \\
\hline & Yes & No & \\
\hline -BMI & $\begin{array}{c}41,13 \mathrm{~kg} / \mathrm{m}^{2} \\
( \pm 4,84)\end{array}$ & $\begin{array}{c}41,22 \mathrm{~kg} / \mathrm{m}^{2} \\
( \pm 4,72)\end{array}$ & $\mathrm{p}^{(1)}=0,786$ \\
\hline - Weight loss after 3 months & $\begin{array}{l}18,73 \mathrm{~kg} \\
( \pm 2,29)\end{array}$ & $\begin{array}{l}17,78 \mathrm{~kg} \\
( \pm 3,20)\end{array}$ & $\mathrm{p}^{(1)}=0,340$ \\
\hline - Weight loss after 6 months & $\begin{array}{l}25,67 \mathrm{~kg} \\
( \pm 2,21)\end{array}$ & $\begin{array}{l}25,23 \mathrm{~kg} \\
( \pm 4,93)\end{array}$ & $\mathrm{p}^{(1)}=0,777$ \\
\hline - Weight loss after 1 year & $\begin{array}{c}33,42 \mathrm{~kg} \\
( \pm 6,97)\end{array}$ & $\begin{array}{l}33,79 \mathrm{~kg} \\
( \pm 5,80)\end{array}$ & $\mathrm{p}^{(1)}=0,758$ \\
\hline
\end{tabular}

(1)=Mann-Whitney Test

TABLE 3 - Variables for group with complications

\begin{tabular}{|c|c|c|c|c|c|c|c|c|c|c|c|}
\hline $\mathrm{n}$ & Age & Gender- & $\frac{\text { BMI pre-op. }}{\left(\mathrm{Kg} / \mathrm{m}^{2}\right)}$ & $\begin{array}{c}\text { CRP pre-op. } \\
\text { (mg/dL) }\end{array}$ & $\begin{array}{c}\text { HbAlc pre-op. } \\
\text { (mg/dL) }\end{array}$ & $\begin{array}{c}\text { Insulin pre-op. } \\
\text { (mg/dL) }\end{array}$ & $\begin{array}{l}\text { Cholest. Total } \\
\text { (mg/dL) }\end{array}$ & $\begin{array}{l}\text { Triglyc. } \\
\text { (mg/dL) }\end{array}$ & $\begin{array}{l}\text { Weight loss } \\
\text { (kg) }-3 \text { months }\end{array}$ & $\begin{array}{l}\text { Weight loss } \\
\text { (kg) }-6 \text { months }\end{array}$ & $\frac{\text { Weight loss }}{(\mathrm{kg})-1 \text { year }}$ \\
\hline 1 & 34 & $M$ & 45,2 & 8,5 & 6,3 & 23,9 & 227 & 182 & 18,6 & 26,2 & 36,5 \\
\hline 2 & 46 & $\mathrm{~F}$ & 42,5 & 4,5 & 6 & 19 & 259 & 135 & 16,5 & 24,8 & 32,2 \\
\hline 3 & 44 & $M$ & 35 & 7,8 & 3,1 & 16 & 314 & 628 & 23,9 & 27 & 30,4 \\
\hline 4 & 64 & $\mathrm{~F}$ & 37 & 4,4 & 6,2 & 11,5 & 247 & 180 & 18 & 26,5 & 24,4 \\
\hline 5 & 32 & $\mathrm{~F}$ & 40,5 & 10,3 & 5,3 & 38 & 179 & 185 & 21 & 23,2 & 26,5 \\
\hline 6 & 58 & $M$ & 49,7 & 7,6 & 5,8 & 14 & 304 & 700 & 20,9 & 25,1 & 30,7 \\
\hline 7 & 41 & $M$ & 41,3 & 3,9 & 5,2 & 5,2 & 237 & 215 & 15,8 & 18,4 & 18,1 \\
\hline
\end{tabular}

$\mathrm{n}=$ patient; $\mathrm{BMI}=$ body mass index; pre-op= preoperative; $\mathrm{CRP}=\mathrm{C}$-reactive protein; Cholest. Total=total cholesterol; Triglyc. $=$ triglycerides.

\section{DISCUSSION}

The inflammatory profile as a marker for postoperative complications has been studied for some surgical specialties by measuring CRP2,8,17,29. However, there are few reports of the relation between serum levels of CRP and complications after RYGB 21,27

Obese patients may exhibit higher levels of CRP owing to the increase in production of interleukin- 6 and tumor necrosis factor in adipocytes, regulating the production of CRP in the

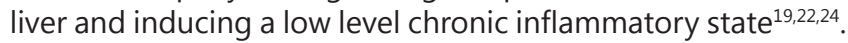
Publications have shown that patients with DM2 have higher levels of CRP and this may also indicate that obese patients with high levels of this protein are at greater risk of developing $\mathrm{DM} 2^{10}$.

Hyperglycemia and DM2 have been associated with higher postoperative morbidity ${ }^{30}$. Some authors thus argue that most hospitalized diabetic patients should receive insulin therapy, according to the severity of the $\mathrm{DM} 2$, to reduce the risk of complications ${ }^{25}$.

In the present study there was no difference in plasma levels of CRP, triglycerides and total cholesterol between diabetics and non-diabetics. This similarity may be explained by the fact that the patients without diabetes were severely obese and thus exhibited strong inflammatory activity, heightened cardiovascular risk and a greater likelihood of progression to $\mathrm{DM} 2^{4,9}$. Furthermore, the patients with $\mathrm{DM} 2$ included in the present study had, on average, only had the disease for a short time. The small sample size should also be considered.

The identification of factors associated with higher risk of surgical complications is important for adequate selection of patients prior to surgery. The classification of these according to degrees of surgical risk enables improved quality of surgical treatment and outcomes ${ }^{14,15}$.

RYGB has a low complications rate compared to other surgical procedures. The incidence of early postoperative complications, such as fistula, varies, on average, from 0.4 to $5.2 \%$ in most studies ${ }^{12}$. However, these complications may be difficult to treat, requiring early intervention and exhibiting high levels of morbidity ${ }^{7}$. Identification of a serum risk factor marker for postoperative complications, such as CPR, may, therefore, be a predictor for severe complications after RYGB, reducing the risks of the procedure.

The present study identified a preoperative CRP of over 3 $\mathrm{mg} / \mathrm{dl}$ as presenting a higher risk of postoperative complications.
It has been shown that preoperative measurement of CRP or the CRP curve is important for stratifying the risk of early surgical complications ${ }^{1,17,26}$.

In vascular lower-limb by-pass surgery, patients with CRP greater than $5 \mathrm{mg} / \mathrm{dl}$ immediately prior to surgery had a higher risk of postoperative vascular complications. Follow-up showed that $60 \%$ of the patients $(21 / 35)$ had complications compared to $32 \%(18 / 56)$ for the group with CRP of less than $5 \mathrm{mg} / \mathrm{dl}(\mathrm{p}=0.004)^{17}$

A study published in 2012 conducted a retrospective analysis of patients undergoing laparoscopic RYGB. Of these, $4.1 \%(n=17)$ developed a fistula after an average of five days. Higher levels of CRP two days after RYGB proved to be of great diagnostic value for predicting postoperative complications especially intestinal leakage ${ }^{27}$.

In general, older patients and those with comorbidities, principally diabetes and hypertension, have a greater risk of developing a fistula and a higher risk of death. This group of patients should thus be avoided at the beginning of the learning curve in order to prevent postoperative complications. Preoperative serum levels of CRP may be a predictor of the occurrence of complications, such as fistulas.

Despite the relation between heightened levels of CRP and the occurrence of postoperative complications having been suggested by various studies, some appear to disagree with this hypothesis. In a meta-analysis carried out by Padayache, in 2009, heightened levels of CRP were not found to be related to a higher incidence of morbidity and/or mortality up to 30 days after surgery ${ }^{18}$.

The possibility of serum markers predictive of complications other than CRP has also been investigated. In a non-randomized prospective cohort study published in 2011, levels of procalcitonin were examined as a possible prognostic parameter for infectious complications in patients with acute spinal cord lesions with and without postoperative infection. The patients who experienced complications $(7.7 \%)$ had significantly higher levels of procalcitonin and CRP compared to those without complications, with procalcitonin being more sensitive than CRP16.

The inflammatory marker CRP may have a role to play in the preoperative routine for grade II or III obesity patients who are candidates for bariatric surgery, as a marker for the risk of immediate postoperative complications or be used to make up part of the score for stratification of surgical risk. High levels of CRP may indicate the need to delay or suspend 
surgery until levels of this protein have been normalized by weight loss and better metabolic control, as a way of avoiding a higher occurrence of immediate postoperative complications.

\section{CONCLUSION}

Preoperative serum levels of $C$ reactive protein were higher in the group with complications after Roux-en-Y gastric by-pass surgery than in the one without complications.

\section{REFERENCES}

1. Ackland GL, ScollayJM, Parks RW, de BeauxI, Mythen MG. Pre-operative high sensitivity C-reactive protein and postoperative outcome in patients undergoing elective orthopaedic surgery. Anaesthesia. 2007 Sep;62(9):888-94. PMID: 17697214. Epub 2007/08/19.

2. Adamina M, Steffen T, Tarantino I, BeutnerU, Schmied BM, Warschkow R. Meta-analysis of the predictive value of $\mathrm{C}$-reactive protein for infectious complications in abdominal surgery. Br J Surg. 2015 May;102(6):590-8. PMID: 25776855. Epub 2015/03/18.

3. AgrawalV, Krause KR, Chengelis DL, Zalesin KC, Rocher LL, McCullough PA. Relation between degree of weight loss after bariatric surgery and reduction in albuminuria and C-reactive protein. Surg Obes Relat Dis. 2009 Jan-Feb:5(1):20-6. PMID: 18951068. Epub 2008/10/28.

4. Bochud M, Marquant F, Marques-Vidal PM, Vollenweider P, Beckmann JS, Mooser V, et al. Association between C-reactive protein and adiposity in women. J Clin Endocrinol Metab. 2009 Oct;94(10):396977. PMID: 19584180. Epub 2009/07/09.

5. Buchwald H, EstokR, Fahrbach K, Banel D, Sledge I. Trends in mortality in bariatric surgery: a systematic review and meta-analysis. Surgery. 2007 Oct;142(4):621-32; discussion 32-5. PMID: 17950357. Epub 2007/10/24.

6. BulloM,Garcia-LordaP,MegiasI,Salas-SalvadoJ.Systemicinflammation, adipose tissue tumor necrosis factor, and leptin expression. Obes Res. 2003 Apr;11(4):525-31. PMID: 12690081. Epub 2003/04/12.

7. Campos JM, Pereira EF, Evangelista LF, Siqueira L, Neto MG, Dib V, et al. Gastrobronchial fistula after sleeve gastrectomy and gastric bypass: endoscopic management and prevention. Obes Surg. 2011 Oct;21(10):1520-9. PMID: 21643779. Epub 2011/06/07.

8. Cappabianca G, Paparella D, Visicchio G, Capone G, Lionetti G, Numis $\mathrm{F}$, et al. Preoperative $\mathrm{C}$-reactive protein predicts mid-term outcome after cardiac surgery. Ann Thorac Surg.2006 Dec;82(6):2170-8. PMID: 17126130. Epub 2006/11/28.

9. Compher C, Badellino KO. Obesity and inflammation: lessons from bariatric surgery. JPEN J Parenter Enteral Nutr. 2008 NovDec;32(6):645-7. PMID: 18974245. Epub 2008/11/01.

10. Dehghan A, van Hoek M, Sijbrands EJ, Stijnen T, Hofman A, Witteman JC. Risk of type 2 diabetes attributable to $C$-reactive protein and other risk factors. Diabetes Care. 2007 Oct;30(10):2695-9. PMID: 17623828. Epub 2007/07/12.

11. Frisch A, Chandra P, Smiley D, Peng L, Rizzo M, Gatcliffe C, et al. Prevalence and clinical outcome of hyperglycemia in the perioperative period in noncardiac surgery. Diabetes Care. 2010 Aug;33(8):1783-8. PMID: 20435798. Central PMCID: 2909062. Epub 2010/05/04.

12. Griffith PS, Birch DW, Sharma AM, KarmaliS. Managing complications associated with laparoscopic Roux-en-Y gastric bypass for morbid obesity. Can J Surg. 2012 Oct;55(5):329-36. PMID: 22854113. Central PMCID: 3468646. Epub 2012/08/03.

13. Manco M, Fernandez-Real JM, Equitani F, Vendrell J, Valera Mora $\mathrm{ME}, \mathrm{Nanni} \mathrm{G}$, et al. Effect of massive weight loss on inflammatory adipocytokines and the innate immune system in morbidly obese women. J Clin Endocrinol Metab. 2007 Feb;92(2):483-90. PMID: 17105839. Epub 2006/11/16.

14. Martins-Filho ED, Câmara-Neto JB, Ferraz ÁAB, Amorim M, Ferraz EM. Evaluation of risk factors in superobese patients submitted to conventional Fobi-Capella surgery. Arquivos de Gastroenterologia. 2008;45:3-10.
15. Martins-Filho ED, Katz L, Amorim M, FerrazÁAB, FerrazEM. Prediction of severe complicatons and death in superobese patients undergoing opengastric bypass withthe RecifeScore.Arquivos de Gastroenterologia. 2011:48:8-14.

16. Nie H, Jiang D, Ou Y, Quan Z, Hao J, Bai C, et al. Procalcitonin as an early predictor of postoperative infectious complications in patients with acute traumatic spinal cord injury. Spinal Cord. 2011 Jun;49(6):715-20. PMID: 21243003. Epub 2011/01/19.

17. Owens CD, Ridker PM, Belkin M, Hamdan AD, Pomposelli F, Logerfo $F$, et al. Elevated $C$-reactive protein levels are associated with postoperative events in patients undergoing lower extremity vein bypass surgery. J Vasc Surg. 2007 Jan;45(1):2-9; discussion. PMID: 17123769. Central PMCID: 3488442. Epub 2006/11/25.

18. Padayachee L, Rodseth RN, Biccard BM. A meta-analysis of the utility of C-reactive protein in predicting early, intermediate-term and long term mortality and major adverse cardiac events in vascular surgical patients. Anaesthesia. 2009Apr;64(4):416-24.PMID:19317708. Epub 2009/03/26.

19. Pelascini E, Disse E, Pasquer A, Poncet G, Gouillat C, Robert M. Should we wait for metabolic complications before operating on obese patients? Gastric bypass outcomes in metabolically healthy obese individuals. Surg Obes Relat Dis. 2015 May 8. PMID:26164112. Epub 2015/07/15.

20. RizviAA. Hypertension, obesity, and inflammation:the complexdesigns of a deadly trio. Metab Syndr Relat Disord. 2010 Aug;8(4):287-94. PMID: 20367224. Epub 2010/04/07.

21. Romain B, Chemaly R, Meyer N, Chilintseva N, Triki E, Brigand C, et al. Diagnostic markers of postoperative morbidity after laparoscopic Roux-en-Y gastric bypass for obesity. Langenbecks Arch Surg. 2014 Apr;399(4):503-8. PMID: 24643459. Epub 2014/03/20.

22. Santos J, Salgado P, Santos C, Mendes P, Saavedra J, Baldaque P, et al. Effect of bariatric surgery on weight loss, inflammation, iron metabolism, and lipid profile. Scand J Surg. 2014 Mar;103(1):21-5. PMID: 24177986. Epub 2013/11/02.

23. Sjostrom L, Lindroos AK, Peltonen M, Torgerson J, Bouchard C, Carlsson $B$, et al. Lifestyle, diabetes, and cardiovascular risk factors 10 years after bariatric surgery. N Engl J Med. 2004 Dec 23;351(26):2683-93. PMID: 15616203. Epub 2004/12/24.

24. Trayhurn P, Wood IS. Adipokines: inflammation and the pleiotropic role of white adipose tissue. Br J Nutr. 2004 Sep;92(3):347-55. PMID: 15469638. Epub 2004/10/08.

25. Umpierrez G. How to manage type 2 diabetes in medical and surgical patients in the hospital. Cleveland Clinic Journal of Medicine. 2011 June;78(6).

26. Warschkow R, Beutner U, Steffen T, Muller SA, Schmied BM, Guller $U$, et al. Safe and early discharge after colorectal surgery due to C-reactive protein: a diagnostic meta-analysis of 1832 patients. Ann Surg. 2012 Aug;256(2):245-50. PMID: 22735714. Epub 2012/06/28.

27. Warschkow R, Tarantino I, Folie P, Beutner U, Schmied BM, Bisang $P$, et al. C-reactive protein 2 days after laparoscopic gastric bypass surgery reliably indicates leaks and moderately predicts morbidity. J Gastrointest Surg. 2012 Jun;16(6):1128-35. PMID: 22528569. Epub 2012/04/25.

28. Wellen KE, Hotamisligil GS. Inflammation, stress, and diabetes. J Clin Invest. 2005 May;115(5):1111-9. PMID: 15864338. Central PMCID: 1087185. Epub 2005/05/03.

29. Woeste G, Muller C, Bechstein WO, Wullstein C. Increased serum levels of $C$-reactive protein precede anastomoticleakage in colorectal surgery. World J Surg. 2010 Jan;34(1):140-6. PMID: 19953248. Epub 2009/12/03.

30.Zagorski SM, Papa NN, Chung MH. The effect of weight loss after gastric bypass on C-reactive protein levels. Surg Obes Relat Dis. 2005 Mar-Apr;1(2):81-5.. PMID: 16925219. Epub 2006/08/24. 